\title{
THE EFFECT OF DIFFERENT SOURCE OF IRON ON NUTRITIONAL VALUE OF GREENHOUSE TOMATO FRUIT GROWN IN PEAT SUBSTRATE
}

\author{
Piotr CHOHURA ${ }^{1}$, Eugeniusz KOŁOTA ${ }^{1}$, Andrzej KOMOSA ${ }^{2}$ \\ ${ }^{1}$ Wrocław University of Environmental and Life Sciences, Department of Horticulture \\ Grunwaldzki Sq. 24A, 50-363 Wrocław, Poland \\ ${ }^{2}$ August Cieszkowski University of Poznań \\ Dąbrowskiego 159, 60-594 Poznań, Poland
}

Received: August 21, 2007; Accepted: October 10, 2007

\begin{abstract}
Summary
The aim of the investigations conducted in 2005-2006 was to estimate the effect of different kind of iron chelates: Fe 8 Forte (EDTA), Top 13 (EDTA+DTPA) and Librel Fe DP7 (DTPA) and iron concentration 50, 75 and $100 \mathrm{mg} \mathrm{Fe} \cdot \mathrm{dm}^{-3}$ in growing medium on the yield and fruit quality of greenhouse tomato $\mathrm{cv}$. 'Merkury $\mathrm{F}_{1}$ '. Tomato plants were grown in peat substrate produced by Hartmann, which characterized natural low iron content. The experiment was set up in two factorial design in three replications. One plot covered 6 plants grown in spacing $0.6 \times 0.5 \mathrm{~m}$, plant population was 3.0 per $1 \mathrm{~m}^{2}$. The best yield of greenhouse tomato cv. 'Merkury $\mathrm{F}_{1}$ ' was recorded when Fe 8 Forte in 75 $\mathrm{mg} \mathrm{Fe} \cdot \mathrm{dm}^{-3}$ while Fe 13 Top and Librel Fe DP7 in concentration of $100 \mathrm{mg}$ $\mathrm{Fe} \cdot \mathrm{dm}^{-3}$ were used. There was not recorded any strongly effect of tested fertilizers and iron concentration in substrate on the nutritional value of fruits.
\end{abstract}

key words: greenhouse tomato, iron, chelates, yield, fruit nutritional value

\section{INTRODUCTION}

Iron is one of the essential nutrients for growth and development of plants which influences the crop yield and its quality. The visible symptom of iron deficiency is the youngest leaf chlorosis due to the reduction of the chlorophyll content in leaves. Deficiency symptoms observed in plants in most cases does not mean a deficiency of this element in the growing medium but rather disability of the plant to take it up. In horticultural practice it often happens problem with correct iron feeding because of its easy transfer into less available form for plants (Bergmann 1992). The main chemical factors determining the level of soluble iron content in the soil solution are: oxidation-reduction reactions and the $\mathrm{pH}$. Iron's ions $\mathrm{Fe}^{+2}$ in anaerobic conditions quickly change their valence for $\mathrm{Fe}^{+3}$ and in this way become more difficult available for plants roots. Moreover,

Corresponding author:

e-mail: chohura@ozi.ar.wroc.pl

(C) Copyright by RIVC 
lower iron availability may by caused by high concentration of phosphates and carbonates in growing medium. Principle meaning in iron protection against retrogradation is its using in chelate forms, which characterizes good solubility in water and low constant dissociation (Wreesmann 1996).

From such fertilizers Fe cations are gradually released to soil solution or can be absorbed as organic-mineral complex. Durability and availability of iron from chelats considerably depend on ligand properties (Komosa et al. 2005).

The aim of the present investigation was the evaluation of suitability of three iron chelates and different iron concentration in the medium for greenhouse tomato grown in peat substrate, taking into account the yield, and nutritional value of fruit.

\section{MATERIAL AND METHODS}

Greenhouse experiments were conducted in 2005 and 2006 at the Piastów Horticultural Experimental Station. First experimental factor covered three iron chelates: Fe 8 Forte (EDTA), Fe 13 Top (EDTA+DTPA) i Librel Fe DP7 (DTPA) and the second one was the content of iron in peat substrate: 50, 75 and $100 \mathrm{mg} \mathrm{Fe} \cdot \mathrm{dm}^{-3}$.

Seeds of cv. Merkury $F_{1}$ were sown on 18 February 2005 and 3 March 2006. Seedlings were planted in the first decade of April, at the beginning of the first truss blossoming in benches filled with peat substrate supplied by Hartmann, which characterized natural low iron content.

$\mathrm{pH}$ of peat was raised up to the level 6.0 by using calcium carbonate in the amounts calculated on the base on neutralization curve for tomato optimum (Breś et al. 2003). The content of macro- and microelements were raised up to standard level for tomato [in $\left.\mathrm{mg} \cdot \mathrm{dm}^{-3}\right]$ : $\mathrm{N}-220, \mathrm{P}-180, \mathrm{~K}-350, \mathrm{Ca}-1500, \mathrm{Mg}$ - 200, Mn - 20, Zn - 20, Cu - 5.0, B - 1.5, Mo - 1.5 (Komosa 2005). In third decade of June plants were supplementary fertilized by addition $5 \mathrm{~g} \mathrm{~N}$ and $10 \mathrm{~g}$ $\mathrm{K}$ for $1 \mathrm{~m}^{2}$ of the cultivated area. The experiment was set up in two factorial design in three replications. One plot covered 6 plants grown in spacing $0.6 \mathrm{x}$ $0.5 \mathrm{~m}$, which assured the population of 3.0 plants per $1 \mathrm{~m}^{2}$. The volume of peat was $50 \mathrm{dm}^{3}$ per plant.

Plants were trained to a single stem, and grown for 5 trusses. During the growing period lower leaves located below fruiting truss were removed, and the number of flowers per one truss was reduced to 5-6. Bombus terrestris for plant pollination was used. At harvest conducted usually twice a week, the fruit were weighed and sorted out into following grades: IA> $6.5 \mathrm{~cm}$, IB $4.5-6.0 \mathrm{~cm}$, II $3.5-4.5 \mathrm{~cm}$. All this fruits represented marketable yield of tomatoes.

Nutritional value of fruits was assessed on the basis of a dry matter (method of drying to the constant weight at $105^{\circ} \mathrm{C}$ ), vitamin $\mathrm{C}$ (Tillman's method), reducing and total sugars content (Lane-Eynon method), $\mathrm{P}$ and $\mathrm{Mg}$ (calorimetrically), $\mathrm{K}$ and $\mathrm{Ca}$ (photometric method). 
The obtained results of the study were subjected to statistical analyse elaboration involving variance analyses and confidence intervals according to Tukey test for significant level at $\mathrm{P}=0.05$.

\section{RESULTS AND DISCUSSION}

The best yielding of tomato plants was obtained in treatment Fe 8 Forte use as a source of iron fertilization. Mean total yield of fruit harvested from plants supplied by Fe 8 Forte equal to $13.15 \mathrm{~kg} \cdot \mathrm{m}^{-2}$, was significantly higher in comparison to the other tested fertilizers (Table 1). Plants fertilized by $\mathrm{Fe} 13$ Top and Librel Fe DP7 yielded on the same level, and the differences were not statistically proved. Similar effect was observed by Komosa et al. (2002) in the study with tomato grown in rockwool and fed with different iron chelates.

Table 1. The effect of the kind of chelates and iron concentration on yielding of greenhouse tomato cv. 'Merkury $\mathrm{F}_{1}$ ' grown in peat substrate (mean for 2005-2006)

\begin{tabular}{|c|c|c|c|c|}
\hline \multirow{3}{*}{ Kind of fertilizer } & \multicolumn{4}{|c|}{ Fe level in $\mathrm{mg} \cdot \mathrm{dm}^{-3}$ of peat substrate } \\
\hline & 50 & 75 & 100 & \\
\hline & \multicolumn{3}{|c|}{ Total yield $\left(\mathrm{kg} \cdot \mathrm{m}^{-2}\right)$} & Mean \\
\hline Fe 13 Top & 12.03 & 12.00 & 12.96 & 12.33 \\
\hline Fe 8 Forte & 12.80 & 13.42 & 13.22 & 13.15 \\
\hline Librel Fe DP7 & 11.51 & 12.43 & 13.61 & 12.52 \\
\hline Mean & 12.11 & 12.62 & 13.27 & \\
\hline \multicolumn{5}{|c|}{$\begin{array}{l}\mathrm{LSD}_{\mathrm{P}=0.05} \text { for: } \\
\text { kind of fertilizer }-0.54 \text {, Fe dose }-0.51 \text {, interaction }-0.58\end{array}$} \\
\hline & \multicolumn{3}{|c|}{ Marketable yield $\left(\mathrm{kg} \cdot \mathrm{m}^{-2}\right)$} & Mean \\
\hline Fe 13 Top & 11.50 & 11.57 & 12.43 & 11.83 \\
\hline Fe 8 Forte & 12.22 & 12.96 & 12.79 & 12.66 \\
\hline Librel Fe DP7 & 11.18 & 11.94 & 12.07 & 11.73 \\
\hline Mean & 11.64 & 12.16 & 12.43 & \\
\hline $\begin{array}{l}\mathrm{LSD}_{\mathrm{P}=0.05} \text { for: } \\
\text { kind of fertilize }\end{array}$ & & & & \\
\hline
\end{tabular}

Data of the study proved that increasing Fe content from 50 to 75 and 100 $\mathrm{mg} \mathrm{Fe} \cdot \mathrm{dm}^{-3}$ in growing medium affected significant increment of total yield of tomato fruits from 12.11 to 12.62 and $13.27 \mathrm{~kg} \cdot \mathrm{m}^{-2}$, respectively. Similar effect for comparable growing period was reported by Osińska \& Kołota (1995). Statistical analyses showed a significant interaction between tested factors (Table 1). The highest total tomato yields were harvested in the case when Fe 13 Top and Librel Fe DP7 were used in concentration $100 \mathrm{mg} \mathrm{Fe} \cdot \mathrm{dm}^{-3}$ while in treatment with Fe 8 Forte the maximum yield of fruits was achieved at the level of $75 \mathrm{mg} \mathrm{Fe} \cdot \mathrm{dm}^{-3}$.

Similar to the total yield the highest marketable tomato yield fruits -12.66 $\mathrm{kg} \cdot \mathrm{m}^{-2}$ was picked up from plants fertilized by Fe 8 Forte. Differences between marketable yields from plants supplied by Fe 13 Top and Librel Fe DP7 were not statistically proved. Increasing of Fe content from 50 to $75 \mathrm{mg} \mathrm{Fe} \cdot \mathrm{dm}^{-3}$ in 
growing medium affected significant increment of tomato mean marketable yield from 11.64 do $12.16 \mathrm{~kg} \cdot \mathrm{m}^{-2}$, respectively. Further enrichment of growing medium in $\mathrm{Fe}$ to $100 \mathrm{Fe} \cdot \mathrm{dm}^{-3}$ caused only a slight marketable yield increment.

The highest marketable tomato yields was achieved when Fe 13 Top and Librel Fe DP7 Fe were used in concentration of $100 \mathrm{mg} \mathrm{Fe} \cdot \mathrm{dm}^{-3}$ in growing medium. In treatment where $\mathrm{Fe} 8$ Forte was used as a source of $\mathrm{Fe}$, maximum marketable yield was obtained by application of $75 \mathrm{mg} \mathrm{Fe} \cdot \mathrm{dm}^{-3}$. In the case of Fe 8 Forte and Librel Fe DP7 Fe differences between marketable yields received at the levels 75 and $100 \mathrm{mg} \mathrm{Fe} \cdot \mathrm{dm}^{-3}$ were not significant

Vitamin C content in fruits decreased from 20.19 do $17.50 \mathrm{mg} \cdot 100 \mathrm{~g} \mathrm{f.m} .^{-1}$ along with $\mathrm{Fe}$ concentration increase in growing medium (Table 2). Tomato fruits from plants supplied by Fe 13 Top accumulated higher amounts of this vitamin than by the other chelates. These data were similar to those reported by Chohura \& Kołota (2007). Lower content of vitamin C in cv. 'Merkury F' fruits was reported by Biesiada \& Kołota 2007.

The content of dry matter in fruits was not significantly differentiated among experimental treatment and ranged from 5.21\% to 6.19 (Table 2). Lower content of dry mater in 'Merkury F' cv. fruits was reported by Biesiada \& Kołota 2007.

Table 2. The effect of the kind of chelates and iron concentration on vitamin $\mathrm{C}$ and dry matter content in fruit of greenhouse tomato cv. 'Merkury $\mathrm{F}_{1}$ ' (mean for 20052006)

\begin{tabular}{|c|c|c|c|c|}
\hline \multirow{3}{*}{ Kind of fertilizer } & \multicolumn{3}{|c|}{$\begin{array}{l}\text { Fe level in } \mathrm{mg} \cdot \mathrm{dm}^{-3} \text { of peat } \\
\text { substrate }\end{array}$} & \multirow{3}{*}{ Mean } \\
\hline & 50 & 75 & 100 & \\
\hline & \multicolumn{3}{|c|}{ Dry matter $(\%)$} & \\
\hline Fe 13 Top & 6.19 & 5.21 & 5.97 & 5.79 \\
\hline Fe 8 Forte & 5.39 & 5.55 & 5.57 & 5.50 \\
\hline Librel Fe DP7 & 5.54 & 5.95 & 5.35 & 5.61 \\
\hline \multirow[t]{2}{*}{ Mean } & 5.71 & 5.57 & 5.63 & \\
\hline & \multicolumn{3}{|c|}{ Vitamin C (mg.100g f.m..$\left.^{-1}\right)$} & \\
\hline Fe 13 Top & 22.29 & 18.14 & 18.72 & 19.72 \\
\hline Fe 8 Forte & 19.95 & 19.26 & 17.03 & 18.75 \\
\hline Librel Fe DP7 & 18.33 & 18.72 & 16.76 & 17.94 \\
\hline Mean & 20.19 & 18.71 & 17.50 & \\
\hline
\end{tabular}

There were observed only small differences in the total and reducing sugars concentration in fruits depending on used fertilizers (Table 3). Biesiada \& Kołota 2007 reported higher content of sugars in fruits cv. 'Merkury F' while Chohura \& Kołota (2007) obtained similar results. 
Table 3. The effect of the kind of chelates and iron concentration on total and reducing sugars content in fruit of greenhouse tomato cv. 'Merkury $F_{1}$ ' (mean for 20052006)

\begin{tabular}{|c|c|c|c|c|}
\hline \multirow{3}{*}{ Kind of fertilizer } & \multicolumn{3}{|c|}{$\begin{array}{l}\text { Fe level in } \mathrm{mg} \cdot \mathrm{dm}^{-3} \text { of peat } \\
\text { substrate }\end{array}$} & \multirow{3}{*}{ Mean } \\
\hline & 50 & 75 & 100 & \\
\hline & \multicolumn{3}{|c|}{ Total sugars $\left(\mathrm{g} \cdot 100 \mathrm{~g}\right.$ f.m..$\left.^{-1}\right)$} & \\
\hline Fe 13 Top & 2.90 & 2.75 & 2.89 & 2.85 \\
\hline Fe 8 Forte & 2.88 & 2.65 & 2.80 & 2.78 \\
\hline Librel Fe DP7 & 2.80 & 2.75 & 2.90 & 2.82 \\
\hline \multirow[t]{2}{*}{ Mean } & 2.86 & 2.72 & 2.86 & \\
\hline & \multicolumn{3}{|c|}{ Reducing sugars $\left(\mathrm{g} \cdot 100 \mathrm{~g} \mathrm{f.m} .^{-1}\right)$} & \\
\hline Fe 13 Top & 2.42 & 2.53 & 2.40 & 2.45 \\
\hline Fe 8 Forte & 2.60 & 2.40 & 2.58 & 2.53 \\
\hline Librel Fe DP7 & 2.50 & 2.45 & 2.75 & 2.57 \\
\hline Mean & 2.51 & 2.46 & 2.58 & \\
\hline
\end{tabular}

Generally there were observed no differences in phosphorus, calcium and magnesium content in fruits depending on tested factors (Table $4 \& 5$ ). The highest mean concentration of potassium in fruits was recorded when Librel Fe DP7 was used and by iron level $50 \mathrm{mg} \mathrm{Fe} \cdot \mathrm{dm}^{-3}$.

Table 4. The effect of the kind of chelates and iron concentration on phosphorus and potassium content in fruit of greenhouse tomato cv. 'Merkury $\mathrm{F}_{1}$ ' (mean for 2005-2006)

\begin{tabular}{|c|c|c|c|c|}
\hline \multirow{3}{*}{ Kind of fertilizer } & \multicolumn{3}{|c|}{$\begin{array}{l}\text { Fe level in } \mathrm{mg} \cdot \mathrm{dm}^{-3} \text { of peat } \\
\text { substrate }\end{array}$} & \multirow{3}{*}{ Mean } \\
\hline & 50 & 75 & 100 & \\
\hline & \multicolumn{3}{|c|}{ Phosphorus (mg P.100g f.m..$^{-1}$ ) } & \\
\hline Fe 13 Top & 30.39 & 24.22 & 22.99 & 25.87 \\
\hline Fe 8 Forte & 24.23 & 26.99 & 23.33 & 24.85 \\
\hline Librel Fe DP7 & 24.01 & 24.52 & 28.00 & 25.51 \\
\hline \multirow[t]{2}{*}{ Mean } & 26.21 & 25.24 & 24.77 & \\
\hline & \multicolumn{3}{|c|}{ Potassium (mg K·100g f.m. $\left.{ }^{-1}\right)$} & \\
\hline Fe 13 Top & 280.16 & 263.89 & 251.26 & 265.10 \\
\hline Fe 8 Forte & 246.95 & 238.81 & 267.86 & 251.20 \\
\hline Librel Fe DP7 & 282.11 & 258.06 & 276.48 & 272.22 \\
\hline Mean & 269.74 & 253.59 & 265.20 & \\
\hline
\end{tabular}


Table 5. The effect of the kind of chelates and iron concentration on calcium and magnesium content in fruit of greenhouse tomato cv. 'Merkury $\mathrm{F}_{1}$ ' (mean for 20052006)

\begin{tabular}{|c|c|c|c|c|}
\hline \multirow{3}{*}{ Kind of fertilizer } & \multicolumn{3}{|c|}{$\begin{array}{l}\text { Fe level in } \mathrm{mg} \cdot \mathrm{dm}^{-3} \text { of peat } \\
\text { substrate }\end{array}$} & \multirow{3}{*}{ Mean } \\
\hline & 50 & 75 & 100 & \\
\hline & \multicolumn{3}{|c|}{ Calcium (mg Ca·100g f.m. ${ }^{-1}$ ) } & \\
\hline Fe 13 Top & 16.15 & 12.50 & 16.02 & 14.89 \\
\hline Fe 8 Forte & 13.07 & 13.73 & 13.10 & 13.30 \\
\hline Librel Fe DP7 & 13.51 & 14.19 & 13.39 & 13.70 \\
\hline \multirow[t]{2}{*}{ Mean } & 14.24 & 13.47 & 14.17 & \\
\hline & \multicolumn{3}{|c|}{ Magnesium (mg Mg.100g f.m..$\left.^{-1}\right)$} & \\
\hline Fe 13 Top & 22.74 & 20.28 & 19.79 & 20.94 \\
\hline Fe 8 Forte & 18.59 & 18.81 & 19.94 & 19.11 \\
\hline Librel Fe DP7 & 20.11 & 19.03 & 20.08 & 19.74 \\
\hline Mean & 20.48 & 19.37 & 19.94 & \\
\hline
\end{tabular}

\section{CONCLUSIONS}

1. Chelate Fe 8 Forte appeared to be a better source of iron for tomato plants grown in peat substrate than Fe 13 Top or commonly used for this purposes Librel Fe DP7.

2. The maximum yield of fruits was produced at the level of $75 \mathrm{mg} \mathrm{Fe} \cdot \mathrm{dm}^{-3}$ in treatment with Fe 8 Forte application or $100 \mathrm{mg} \mathrm{Fe} \cdot \mathrm{dm}^{-3}$ if the other source of this nutrient was used.

3. The quality of fruits expressed by the content of dry matter, sugars, vitamin $\mathrm{C}$ and macroelements was not influenced by the source and level of Fe applied to the growing medium.

\section{REFERENCES}

Biesiada A., Kołota E. 2007. Evaluation of some new greenhouse tomato cultivars for production on benches. Spontaneous and induced variation for the genetic improvement of horticultural crops. University Press. University of Technology and Life Sciences in Bydgoszcz: 39-44.

Chohura P., Kołota E. 2007. Evaluation of yielding and fruit quality of some new greenhouse tomato cultivars for growing in rockwool. Spontaneous and induced variation for the genetic improvement of horticultural crops. University Press. University of Technology and Life Sciences in Bydgoszcz: 75-80.

Bergmann W. 1999. Nutritional disorders of plants. Development, visual and analytical diagnosis. Gustaw Fischer Verlag Jena, Stuttgart, New York: 133-151, 247-266.

Breś W., Golcz A., Komosa A., Kozik E., Tyksiński W. 2003. Nawożenie roślin ogrodniczych. Wyd. AR Poznań. [in Polish]

Komosa A. 2005. Aktualne tendencje w żywieniu roślin warzywnych uprawianych pod osłonami. Zesz. Nauk. AR we Wrocławiu. Rolnictwo LXXXVI. 515: 265-277. [in Polish]

Komosa A., Kołota E., Chohura P. 2002. Usefulness of iron chelates for fertilization of greenhouse tomato cultivated in rockwool. Veget. Crop Res. Bull. 55: 35-40. 
Komosa A., Chohura P., Roszyk J. 2005. Wpływ temperatury i czasu użytkowania pożywki na zawartość żelaza dostępnego w chelatach żelazowych. Zesz. Nauk. AR we Wrocławiu, Rolnictwo LXXXVI. 515: 259-265. [in Polish]

Osińska M., Kołota E. 1995. Ocena przydatności Multivitu do nawożenia pomidora szklarniowego. Ogólnopolska Konferencja Naukowa „Nowe technologie a jakość plonowania warzyw" Wrocław. 143-145. [in Polish]

Wreesmann C. 1996. Chelated micro-nutrients for soilless culture. ISOSC, Proceedings. 559-572.

\section{WPŁYW ZRÓŻNICOWANEGO NAWOZENIA ŻELAZEM \\ NA WARTOŚĆ ODŻYWCZĄ OWOCÓW POMIDORA SZKLARNIOWEGO UPRAWIANEGO W SUBSTRACIE TORFOWYM}

\section{Streszczenie}

W doświadczeniach szklarniowych przeprowadzonych w latach 2005-2006 badano wpływ kilku chelatów żelazowych: Fe 8 Forte (EDTA), Top 13 (EDTA+DTPA) i Librel Fe DP7 (DTPA) na plonowanie i jakość owoców pomidora szklarniowego odmiany 'Merkury $\mathrm{F}_{1}$ '. Drugi czynnik badawczy obejmował zróżnicowane nawożenie żelazem, zastosowano trzy poziomy jego koncentracji w podłożu tj.: 50, 75 i $100 \mathrm{mg}$ $\mathrm{Fe} \cdot \mathrm{dm}^{-3}$. Rośliny uprawiano $\mathrm{w}$ substracie torfowym przygotowanym $\mathrm{z}$ torfu firmy Hartmann charakteryzującym się niską naturalną zawartością żelaza. Uprawę prowadzono na stołach w cyklu wiosennym na 5 gron. Rozsadę posadzono w rozstawie $0,6 \times 0,5 \mathrm{~m}$ w zagęszczeniu $3 \mathrm{szt} \cdot \mathrm{m}^{-2}$. Najlepsze plonowanie pomidora odmiany 'Merkury $\mathrm{F}_{1}{ }^{\prime}$ uzyskano po zastosowaniu Fe 8 Forte $\mathrm{w}$ dawce $75 \mathrm{mg} \mathrm{Fe} \cdot \mathrm{dm}^{-3}$ oraz Fe 13 Top i Librel Fe DP7 w stężeniu $100 \mathrm{mg} \mathrm{Fe} \cdot \mathrm{dm}^{-3}$. Nie stwierdzono istotnego wpływu badanych chelatów i dawek żelaza na oceniane cechy jakościowe owoców pomidora, które kształtowały się na typowym poziomie. 